Contents lists available at Journal Redwhitepress
Journal of Educational and Learning Studies
ISSN: 2655-2760 (Print) ISSN: 2655-2779 (Electronic)
Journal homepage: http://journal.redwhitepress.com/index.php/iles

\title{
Student Absence Following Classical Learning Activities and Roles of Information Services
}

\author{
Adif Jawadi Saputra ${ }^{1}$, Prayitno ${ }^{1}$, Yahya Jaya ${ }^{2}$ \\ ${ }^{1}$ Universitas Negeri Padang \\ ${ }^{2}$ Univesitas Islam Negeri Imam Bonjol Padang
}

\begin{tabular}{l}
\hline Article Info \\
\hline Article history: \\
Received Jan $15^{\text {th }}, 2019$ \\
Revised Apr $20^{\text {th }}, 2019$ \\
Accepted Aug $12^{\text {th }}, 2019$ \\
\hline
\end{tabular}

\section{Keyword:}

Student absence

Classical learning activities

Information services

\begin{abstract}
Many problems the absence of students is one of the things that causes the learning process is not optimal and this becomes an important role of guidance and counseling services through information services. The purpose of this study was to reveal the forms of student absence and the quality of the implementation of information services about absenteeism. This type of research is quantitative descriptive research, the sample used was 123 students using porous sampling technique. Data collected using questionnaire absenteeism and the scale of the implementation of information services about student absence (33 items valid $=0.851$ ). Data analysis using percentage analysis and also t-test. The results showed that the most absent form of the students did was not entering school without permission 35 (28.4\%) times and the least was days not going to school ie $2(1.6 \%)$ times. The results showed that there was no significant difference in the implementation of information services about student absenteeism both conducted by state high school and private high school teachers with a good category of $71.67 \%$.
\end{abstract}

(C) 2019 The Authors. Published by Redwhitepress.

This is an open access article under the CC BY-NC-SA license

(https://creativecommons.org/licenses/by-nc-sa/4.0/

\section{Corresponding Author:}

Adif Jawadi Saputra

Universitas Negeri Padang

Email: adifjawadi@gmail.com

\section{Introduction}

Education in its essence is intended to develop the potential that exists within students. Education is a conscious and planned effort to create a learning atmosphere and learning process so that students actively develop their potential to have religious spiritual strength, self-control, personality, intelligence, noble character and skills needed by him, society, nation and state (Undang-Undang, 2013).

Education can be realized well if students do learning activities. Learning is an attempt to master something new in its five dimensions, namely the dimension of knowing, dimensions can, dimensions of want, dimensions of ordinary, dimensions of gratitude and sincerity (Luthfiah, Yuline, \& Wicaksono, n.d.; Prayitno, 2017). Furthermore, attempts to obtain something new can be realized through: "Learning activities by practicing BMB3 dynamics, namely to think, feel, behave, act and be responsible" (Ardi, 2017; D Daharnis \& Ardi, 2017; Fikriyanda, Daharnis, \& Yuca, 2018). Learning activities will not be successful if students do not take advantage of the learning environment and learning process in accordance with the schedule (Arsyad, 2011; Baharun, 2015; Fikriyanda et al., 2018; Suprihatin, 2015). Present following this learning activity is the main requirement for students to master the subject matter through BMB3 activities.

The learning atmosphere occurs in the conditions of the learning process which is usually held in the classroom. Learning is a process of interaction between educators and students where educators direct and 
facilitate students to live the atmosphere of active learning (Luthfiah et al., n.d.; Prayitno, 2017). Students who follow the learning process are certainly present and do not leave the class. To get a better change requires struggle, learning, hard work, dimensional expansion, and the development of optimal potential (Jaya, 2015; Susilana, Si, \& Riyana, 2008). However, there are still many students who do not know the importance of the learning process, so that many absences are found during the lesson. The absence conditions that occur include not attending school, leaving school hours, permitting for various reasons, and not entering again after recess (Annisa Damayanti, 2013; Indayani, Sedanayasa, Antari, \& Erg, 2014; Suprastowo, 2013).

The problem of the absence of students following classical learning activities is a problem that is very often done and needs serious handling, especially through the Guidance and Counseling service (hereinafter abbreviated as BK). "BK services in schools give primary attention to providing sufficient services for students, so that they are able to develop and learn optimally" (Ardi, Ibrahim, \& Said, 2012; Permana, Syahniar, \& Daharnis, 2016; Prayitno, 2009; Prayitno \& Marjohan, 2013; Yuca, Ahmad, \& Ardi, 2017). The quote above gives meaning that the counselor must be able to hold ten types of services and six supporting activities so that students can develop and learn optimally.

Through this information service students get an understanding of things related to their lives, both at school and outside of school. Counselors certainly want the benefits of providing information services. Therefore, to find out the results of the material provided by the BK teacher through information services, it is necessary to look at the functions contained in the BK. Information services can improve student learning discipline (Sanderi \& Sukmawati, 2013).

It was reported the Civil Service Police Unit (satpol PP) conducted a raid on a number of internet cafes in the Lapai area (Padang City) (SindoNews, 2016), found 43 students in high school uniforms playing in an internet cafe. The students were immediately led to the Satpol PP office for guidance and made an agreement not to repeat their actions, before being picked up by their parents. This proves that the absence of students following classical learning activities is one of the problems that often occur in school. In this case, the role of $\mathrm{BK}$ teachers is needed, which must provide services in the form of developing effective daily life and handling the daily life that is disturbed, both in daily life in school and outside the school environment (Ahmadi \& Rohani, 1991; D Daharnis \& Ardi, 2017; Fiana, Daharnis, \& Ridha, 2013; Yuca et al., 2017).

Preliminary data obtained by researchers from one of the high schools in Padang City on January 23, 2017 found that in a class of 35 students, there were 20 students who did not attend classical learning activities on Monday the second lesson, Tuesday 17 students, Wednesday 12 students, Thursday 9 students, Friday 14 students, and Saturday 21 students. Other data obtained by researchers from one of the Padang City Public High Schools in March 2018 found that in one class containing 36 students, in one month there were 16 students without information, 16 students were permitted and 3 students were ill. This indicates that students' learning desires are still very low, which requires more optimal supervision and the role of BK teachers.

Judging from the importance of the learning process in the classroom, it needs to be questioned how is the condition of high school students participating in the classroom learning process? How is the role of BK in providing information services related to handling the absence of students following classical learning activities? If it is revealed that the role of $\mathrm{BK}$ is not appropriate to handle the absence of students participating in classical learning activities, it can mean that the BK service has not been properly implemented. Therefore, it is necessary to conduct a study of, "Student Absence Following Classical Learning Activities and the Role of Information Services".

The purpose of this study was to describe 1) The condition of the students participated in the absence of classical learning in high school into the sample. 2) The quality of the role of BK in providing information services related to the absence of students participating in classical learning activities in high school is the sample.

\section{Method}

Type of research conducted is quantitative descriptive research. Descriptive research is one type of research that aims to describe systematically, factually, and accurately about the facts, and the nature of a particular population, or try to develop phenomena in detail (Yusuf, 2016). The subjects of this study were 123 students using purposive sampling technique. The consideration is that the school has the same accreditation, namely accreditation A. It has a counselor who gets regular hours to provide information services and has counselors with the same qualifications namely undergraduete guidance and counseling. This study aims to see how many students make absences in a certain period of time looking at how the role of the counselor in providing information services is related to the absence of students, so that the technique used in this research 
is purposive sampling. The instrument used was a questionnaire about the absence of students participating in classical learning activities and questionnaires about the quality of information services with regard to the role ofteachers (33 valid items $=0.851)$

\section{Results}

Overview of the absence of Private High School and High School students as the research sample.

Table 1. Recapitulation of forms of absence of students

\begin{tabular}{|c|c|c|c|c|c|c|c|c|c|c|c|c|c|c|c|c|c|c|}
\hline \multirow{3}{*}{$\begin{array}{c}\text { Form of } \\
\text { absence } \\
\text { of }\end{array}$} & \multicolumn{6}{|c|}{ Public High School A } & \multicolumn{6}{|c|}{ Private High School A } & \multicolumn{4}{|c|}{$\begin{array}{l}\text { High School Science \& } \\
\text { Social Sciences }\end{array}$} & \multirow{2}{*}{\multicolumn{2}{|c|}{$\begin{array}{c}\text { Total }(n= \\
123)\end{array}$}} \\
\hline & \multicolumn{2}{|c|}{$\begin{array}{c}\text { IPA (n = } \\
\text { 33) }\end{array}$} & \multicolumn{2}{|c|}{$\operatorname{IPS}(n=31)$} & \multicolumn{2}{|c|}{$\begin{array}{l}\text { Number (n } \\
=64)\end{array}$} & \multicolumn{2}{|c|}{$\begin{array}{c}\text { Science (n } \\
=30)\end{array}$} & \multicolumn{2}{|c|}{$\begin{array}{c}\text { IPS (n = } \\
29)\end{array}$} & \multicolumn{2}{|c|}{$\begin{array}{l}\text { Number (n } \\
=59)\end{array}$} & \multicolumn{2}{|c|}{$\begin{array}{c}\text { IPA (n = } \\
63)\end{array}$} & \multicolumn{2}{|c|}{$\begin{array}{c}\text { IPS (n = } \\
60)\end{array}$} & & \\
\hline & f & $\%$ & f & $\%$ & $\mathbf{f}$ & $\%$ & $\mathbf{F}$ & $\%$ & f & $\%$ & f & $\%$ & $\mathrm{f}$ & $\%$ & $\mathrm{f}$ & $\%$ & f & $\%$ \\
\hline A & 0 & 0 & 0 & 0 & 0 & 0 & 0 & 0 & 2 & 6.67 & 2 & 3.39 & 0 & 0 & 2 & 3.33 & 2 & 1.6 \\
\hline $\mathrm{B}$ & 5 & 15.1 & 10 & 32.26 & 15 & 23.4 & 7 & 23.3 & 13 & 43.3 & 20 & 33.9 & 12 & 19 & 23 & 38.3 & 35 & 28.4 \\
\hline $\mathrm{C}$ & 3 & 9.09 & 3 & 9,677 & 6 & 9.38 & 4 & 13.3 & 3 & 10 & 7 & 11.8 & 7 & 11.1 & 6 & 10 & 13 & 10.5 \\
\hline $\mathrm{D}$ & 2 & 6.06 & 3 & 9677 & 5 & 7.81 & 2 & 6.67 & 2 & 6.67 & 4 & 6.78 & 4 & 6.35 & 5 & 8.33 & 9 & 7.31 \\
\hline $\mathrm{E}$ & 2 & 6.06 & 2 & 6.452 & 4 & 6.25 & 2 & 6.67 & 2 & 6.67 & 4 & 6.78 & 4 & 6.35 & 4 & 6,67 & 8 & 6.50 \\
\hline $\mathrm{F}$ & 2 & 6.06 & 4 & 12.9 & 6 & 9.38 & 2 & 6.67 & 3 & 10 & 5 & 8.47 & 4 & 6.35 & 7 & 11.7 & 11 & 8.94 \\
\hline $\mathrm{G}$ & 3 & 9.09 & 2 & 6.452 & 5 & 7,81 & 3 & 10 & 2 & 6.67 & 5 & 8.47 & 6 & 9.52 & 4 & 6.67 & 10 & 8.13 \\
\hline $\mathrm{H}$ & 2 & 6.06 & 3 & 9677 & 5 & 7.81 & 2 & 6.67 & 1 & 3.33 & 3 & 5.08 & 4 & 6.35 & 4 & 6.67 & 8 & 6.50 \\
\hline $\mathrm{I}$ & 2 & 6.06 & 4 & 12.9 & 6 & 9.38 & 3 & 10 & 6 & 20 & 9 & 15.2 & 5 & 7.94 & 10 & 16.7 & 15 & 12.1 \\
\hline total & 21 & 7.07 & 31 & 11.11 & 52 & 9.52 & 25 & 9.25 & 34 & 13 & 59 & 11.1 & 46 & 7.99 & 65 & 12.0 & 111 & 948 \\
\hline
\end{tabular}

Based on 1 table above it can be seen that from 123 students in August to November 2018 the most frequent form of absenteeism is not entering school without permission (B) as many as 35 (28.6\%), then not entering again after recess (I) with a number of $15(12.2 \%)$, then not entering class returns after certain class hours (C) with a total of $13(10.57 \%)$, invites friends out of class during unfavorable class hours (F) as many as $11(8.94 \%)$, asks permission to leave on grounds of pretending -pura sickness or other reasons $(\mathrm{G})$ as many as $10(8.13 \%)$, not re-entering after asking for permission (D) as many as $9(7.31 \%)$, sending permission to not enter school with fabricated reasons $(\mathrm{H})$ and re-entry to school after changing days $(\mathrm{E})$ by $8(6.50 \%)$ and the least form of absence is days of not attending school (A) with the number $2(1.62 \%)$. So that it can be seen that the overall absence of students is $111(9.48 \%)$. Overall the number of absences of students with various forms was 52 (9.52\%) Public High Schools and 59 (11.1\%) Private High Schools. The overall form of student absence was based on majors, namely $46(7.99 \%)$ for science majors and $65(12.04 \%)$ for Social Sciences majors.

The quality of service information about absences provided by the BK teacher is follows.

Table 2. Quality of Information Service Implementation about Student Absence of Range

\begin{tabular}{ccccc}
\multirow{2}{*}{ Quality Category } & \multirow{2}{*}{ Score } & \multicolumn{2}{c}{ Percentage } & \multicolumn{2}{c}{ Total } \\
\cline { 3 - 4 } & & \% & f & \% \\
\cline { 3 - 5 } & & $87-100$ & 3 & 2.43 \\
\hline Excellent & $138-165$ & $70-86$ & 69 & 56.09 \\
\hline Good & $110-137$ & $54-69$ & 47 & 38.21 \\
\hline Enough & $82-109$ & $37-53$ & 2 & 1,626 \\
\hline Less & $54-81$ & $0-36$ & 0 & 0 \\
\hline More Less & $\leq 53$ & & 123 & 100 \\
\hline Total & & & The \\
\hline
\end{tabular}

Table above illustrates the opinions of students regarding the quality of information services by The BK teacher about the overall absence of students is as follows. As many as $3(2.43 \%)$ of 123 students thought that they were in the very good category, $69(56.09 \%)$ students thought in the good category, then as many as 47 (38.21\%) students were categorized enough, only $2(1.62 \%)$ students in less categories and not students in very less categories. The overall score with an average of 117.75 and the level of achievement of respondents is $71.6 \%$. That is, the opinions of students regarding the quality of information services by BK Counselors about the absence of students at A-accredited Public High Schools and A-accredited Private High Schools in Padang City are both in the category good. 
Table 3. Results of T-Test Test for Information Service Implementation by Counseling Teachers on Student Absence in Schools

\begin{tabular}{cccccc}
\hline No & Respondent & Mean & T & sign. \\
\hline 1 & $\begin{array}{r}\text { Public High } \\
\text { School }\end{array}$ & 119.33 & & 0.182 \\
\hline 2 & $\begin{array}{r}\text { Private High } \\
\text { School }\end{array}$ & 117.25 & 0.888 & & (not significant) \\
\hline
\end{tabular}

Table 3 above illustrates that the quality of the implementation of information services by Counseling Teachers about absence is in the category good with an average score of $118.29(71.67 \%)$ The average score of the results of the implementation at the State High School is higher than the Private High School with a nonsignificant difference, it can be seen from the results of $\mathrm{T}$ count of 0.888 with a significant level of $0.182>$ 0.05. This indicates that there is no significant difference in the provision of information services by the BK Teacher on student absence between Public and Private High Schools. So that it can be concluded that BK teachers in Public High Schools and Private High Schools have provided information services about student absence good.

\section{Discussion}

\section{Student Absence and Its Reason}

The results of the study show that the overall absence of students in the period August 2018 to November 2018 is 111 times. Category forms the most frequent absenteeism is absent from school without permission of a total of $35(31.35 \%)$,then is not signed again after the break with the number $15(13.51 \%)$, and the least form of absence is days of not attending school with $2(1.802 \%)$. This indicates that in a period of 4 months (120 days) on average there is one student absent.

The absence of students in the school certainly causes the learning process not to run optimally, of course what is expected by the school is to develop student potential as optimally as possible. Optimization of learning can be done if the school has rules and school rules. Every school has rules and regulations that must be implemented and obeyed by all students (Slameto, 2010; Yanti, Erlamsyah, Zikra, \& Ardi, 2013). The rules and regulations in question certainly contain elements of BMB3 that make students understand the school rules in which students are disciplined.

Absenteeism is also closely related to the right to and student's obligation, if a student already understands their rights and responsibilities as learners, to be sure the student has understood the importance of following the learning process in the classroom. The rights and obligations of students must be balanced where one of the rights of students is to get new knowledge in learning while the obligation of students is to follow the learning process that has been applied (Pendidikan, 2007; Sa'ud \& Sumantri, 2007). If students already know their rights and obligations, naturally the absence of students following the learning process will be greatly reduced.

The number of student absences must also be a concern of the school. Based on the data found there are 111 forms of student absence occurring in 4 months conducted by 123 students indicating that the level of student discipline still needs to be addressed. Therefore the need for a level of discipline of students needs to be improved again in order to reduce the absence of students in the future. The student discipline was closely related to students' craft in learning and following the learning process (Sanderi \& Sukmawati, 2013). Crafting students in learning will be achieved if students are present in the class to follow the learning process.

Students 'discipline to attend and study in class is also caused by parents' encouragement. Parents who provide support for their children to attend and study at school make their children feel happier and valued. The parental support for student discipline leads to a positive relationship, where students who get parental support are more responsible and obey the rules (Wulandari \& Suhainil, 2017). And it is emphasized again that learning activities are a joint effort between teachers, students and parents (Daharnis Daharnis \& Ardi, 2016; Daharnis Daharnis, Erlamsyah, Ifdil, Ardi, \& Hariko, 2014; Mudjiran, 2015).

\section{The Role of Information Services by Counseling Teachers on Student Absence}

The results of the study describe the opinions of students about information services by Counseling Teachers about student absenteeism as follows. As many as $3(2.43 \%)$ of 123 students argued that they were in a very good category, $69(56.09 \%)$ students thought in the good category, then as many as $47(38.21 \%)$ students were categorized enough, only $2(1.62 \%)$ less and no category students in the very less category. The overall score with an average of 117.75 and the level of achievement of respondents is $71.6 \%$. That is, the 
opinions of students regarding the role of information services by BK teachers on the absence of students in Aaccredited Public High Schools and A-accredited Private High Schools in Padang City are both in the category good.

Regarding the many forms of student absence that have been successfully expressed in research, information services are one of the appropriate services to overcome student absences. Information service is a service in guidance and counseling that intends to provide understanding to interested individuals about various things needed to carry out a desired goal or plan (Azhar \& Daharnis, 2013; Desneli, Firman, \& Sano, 2016; Erwinda, 2016; Luthfiah et al., n.d.; Prayitno, 2017; Prayitno, Wibowo, Marjohan, Mugiharso, \& Ifdil, 2015). The existence of information services about the absence of students is expected to be better able to understand and implement and develop things that can be detrimental if they are not present at school and understand the importance of being present and following the learning process set by the school. Based on differences in types of schools namely Private High School and Public High School in this study, the quality of information service benefits by BK Counselors on the absence of students as a whole in the category good.

\section{Conclusion}

Score of the number of forms of absenteeism in the study sample as a whole is $111(6.83 \%)$ times with the most done is not entering school without permission as many as $35(31.35 \%)$, and the least form of absenteeism is days do not enter school with the number $2(1.802 \%)$. SMA A has a slightly lower score of 52 times compared to A Private High School which has a score of 59 times. The suggest that the implementation of the service information given by counselor to students can be accepted or in the sense of other syudents have been able to catch a message delivered counselor when the provision of the service information. Although there is a difference between the scores of the average National High School student and a private high school but the difference is at an insignificant level. Overall that the implementation of information services provided by counselors bound to absenteeism has been well received by students so that it has an impact on the number of absences made during a certain period of time in low categories.

\section{References}

Ahmadi, A., \& Rohani, A. (1991). Bimbingan dan Konseling. Rineka Cipta, Jakarta.

ANNISA DAMAYANTI, F. (2013). Studi tentang perilaku membolos pada siswa SMA swasta di Surabaya. Jurnal BK Unesa, 3(1).

Ardi, Z. (2017). Unsuitable Majoring: Does the Reorientation Would Help the Student for Revitalize Learning Activities? In 9th International Conference for Science Educators and Teachers (ICSET 2017). Atlantis Press.

Ardi, Z., Ibrahim, Y., \& Said, A. (2012). Capaian Tugas Perkembangan Sosial Siswa dengan Kelompok Teman Sebaya dan Implikasinya terhadap Program Pelayanan Bimbingan dan Konseling. Konselor, $1(2)$.

Arsyad, A. (2011). Media pembelajaran. Jakarta: PT Raja Grafindo Persada.

Azhar, S. K., \& Daharnis, I. S. (2013). Persepsi Siswa Tentang Layanan Informasi Kesehatan Reproduksi Remaja Yang Diberikan Guru Bk Sman 1 Kubung. Jurnal Ilmiah Konseling, 2, 146-150.

Baharun, H. (2015). Penerapan Pembelajaran Active Learning untuk Meningkatkan Hasil Belajar Siswa di Madrasah. PEDAGOGIK: Jurnal Pendidikan, 1(1).

Daharnis, D., \& Ardi, Z. (2016). THE COMPATIBILITY STUDENT CHOICE OF UNIVERSITY MAJORING; A PRELIMINARY STUDIES. GUIDENA: Journal of Guidance and Counseling, Psychology, and Education, 6(1), 101-109.

Daharnis, D., \& Ardi, Z. (2017). Optimizing the Counselors' Role in Senior High School and Higher Education.

Daharnis, D., Erlamsyah, E., Ifdil, I., Ardi, Z., \& Hariko, R. (2014). Gambaran Kegiatan Belajar Siswa Sumatera Barat. In Seminar Internasional Bimbingan dan Konseling (Vol. 1, pp. 1-9).

Desneli, D., Firman, F., \& Sano, A. (2016). Peningkatan Penyesuaian Diri Siswa Melalui Layanan Informasi. Jurnal EDUCATIO: Jurnal Pendidikan Indonesia, 2(2), 9-13. 
Erwinda, L. (2016). URGENSI INTIMACY DALAM KEHIDUPAN BERKELUARGA PASANGAN DEWASA AWAL. Jurnal EDUCATIO: Jurnal Pendidikan Indonesia, 2(2), 53-60.

Fiana, F. J., Daharnis, D., \& Ridha, M. (2013). Disiplin Siswa di Sekolah dan Implikasinya dalam Pelayanan Bimbingan dan Konseling. Konselor, 2(3).

Fikriyanda, F., Daharnis, D., \& Yuca, V. (2018). The Profile of Students Activities; Before, During and After Learning. International Journal of Research in Counseling and Education, 2(1), 49-54.

Indayani, A., Sedanayasa, G., Antari, N. N. M., \& Erg, M. (2014). Penerapan Konseling Behavioral Dengan Teknik Penguatan Positif Sebagai Upaya Untuk Meminimalisasi Perilaku Membolos Pada Siswa Kelas X. 1 Sma Negeri 1 Sawan Tahun Ajaran 2013/2014. Jurnal Ilmiah Bimbingan Konseling Undiksha, 2(1).

Jaya, Y. (2015). Wawasan Profesional Konseling Kekuatan Spiritual Keagamaan dan Ketuhanan Islam. Padang: Hayfa Press.

Luthfiah, Q., Yuline, Y., \& Wicaksono, L. (n.d.). STUDI TENTANG LAYANAN ORIENTASI PADA PESERTA DIDIK KELAS VII DI MTS AL-IRSYAD PONTIANAK. Jurnal Pendidikan Dan Pembelajaran, 7(8).

Mudjiran, M. (2015). Pengembangan Model Penugasan Terstruktur Kepada Siswa. Padang: Sukabina Press.

Pendidikan, B. S. N. (2007). Standar Proses untuk Satuan Pendidikan Dasar dan Menengah. Badan Standar Nasional Pendidikan.

Permana, S. A., Syahniar, S., \& Daharnis, D. (2016). Pelaksanaan Layanan Bimbingan dan Konseling di Sekolah Menengah Atas Negeri (SMAN) 4 Kerinci. Konselor, 3(4), 168-179.

Prayitno, P. (2009). Wawasan Profesional Konseling. Padang: UNP Press.

Prayitno, P. (2017). Konseling Profesional yang Berhasil: Layanan dan Kegiatan Pendukung. Jakarta: Rajawali Press.

Prayitno, P., \& Marjohan, M. (2013). Konseling Integritas. Padang: UNP Press.

Prayitno, P., Wibowo, M. E., Marjohan, M., Mugiharso, H., \& Ifdil, I. (2015). Pembelajaran melalui Pelayanan BK di Satuan Pendidikan: Pengembangan Manusia Seutuhnya. Yogyakarta: Paramitra Publishing.

Sa'ud, U. S., \& Sumantri, M. (2007). Pendidikan dasar dan menengah. Dalam Ilmu \& Aplikasi Pendidikan Bagian, 4.

Sanderi, F., \& Sukmawati, I. (2013). Kepatuhan Siswa Terhadap Disiplin dan Upaya Guru BK dalam Meningkatkannya Melalui Layanan Informasi. Konselor, 2(1).

SindoNews, S. (2016). Pelajar Digaruk dari Warnet Saat jam Belajar. Padang.

Slameto, S. (2010). Belajar dan Faktor-faktor yang Mempengaruhi. Jakarta: Rineka Cipta.

Suprastowo, P. (2013). Kajian Tentang Tingkat ketidakhadiran guru sekolah dasar dan Dampaknya terhadap Siswa. Jurnal Pendidikan Dan Kebudayaan, 19(1), 31-49.

Suprihatin, S. (2015). Upaya guru dalam meningkatkan motivasi belajar siswa. Jurnal Pendidikan Ekonomi UM Metro, 3(1), 73-82.

Susilana, R., Si, M., \& Riyana, C. (2008). Media pembelajaran: hakikat, pengembangan, pemanfaatan, dan penilaian. CV. Wacana Prima.

Undang-Undang, R. I. (2013). No. 20 Tahun 2003 Tentang Sistem Pendidikan Nasional. 2003. Jakarta: Sinar Grafika.

Wulandari, L. R., \& Suhainil, N. (2017). HUBUNGAN DUKUNGAN ORANGTUA DAN TEMAN SEBAYA DENGAN KEDISIPLINAN BELAJAR SISWA. Jurnal Penelitian Bimbingan Dan Konseling, 2(2).

Yanti, S., Erlamsyah, E., Zikra, Z., \& Ardi, Z. (2013). Hubungan antara Kecemasan dalam Belajar dengan Motivasi Belajar Siswa. Konselor, 2(1).

Yuca, V., Ahmad, R., \& Ardi, Z. (2017). The Importance of Infrastructure Facilities in Counseling Services. In 9th International Conference for Science Educators and Teachers (ICSET 2017). Atlantis Press. 
Yusuf, A. M. (2016). Metode penelitian kuantitatif, kualitatif \& penelitian gabungan. Prenada Media. 